\title{
Congenital Hypothyroidism Due To Maternal Radioactive lodine Exposure During Pregnancy
}

\author{
Selim Kurtoğlu1,2, Mustafa Ali Akın1, Ghaniya Daar3, Leyla Akın2, Şeyma Memur1, Levent Korkmaz1, \\ Osman Baştuğ 1 , Selcan Yılmaz1 \\ ${ }^{1}$ Erciyes University Faculty of Medicine, Department of Pediatrics, Division of Neonatology, Kayseri, Turkey \\ ${ }^{2}$ Erciyes University Faculty of Medicine, Department of Pediatric Endocrinology, Kayseri, Turkey \\ ${ }^{3}$ Nevşehir Government Hospital, Department of Pediatrics, Nevşehir, Turkey
}

\begin{abstract}
Radioactive iodine (RAl) is used effectively in the treatment of hyperthyroidism and thyroid cancer, but it is contraindicated during pregnancy. RAI treatment during pregnancy can lead to fetal hypothyroidism, mental retardation and increased malignancy risk in the infant. Pregnancy tests must be performed before treatment in all women of reproductive age. However, at times, RAl is being used before ruling out pregnancy.

We herein present a male newborn infant with congenital hypothyroidism whose mother was given a three-week course of methimazole therapy for her multiple hyperactive nodules and subsequently received $20 \mathrm{mCi}$ RAI during the $12^{\text {th }}$ week of her pregnancy. The patient was referred to our neonatology unit at age two weeks when his thyrotropin (TSH) level was reported to be high in the neonatal screening test. Physical examination was normal. Laboratory investigations revealed hypothyroidism (free triiodothyronine $1.55 \mathrm{pg} / \mathrm{mL}$, free thyroxine $2.9 \mathrm{pg} / \mathrm{mL}$, TSH $452 \mathrm{mU} / \mathrm{L}$, thyroglobulin $20.1 \mathrm{ng} / \mathrm{mL}$ ). The thyroid gland could not be visualized by ultrasonography. L-thyroxine treatment was initiated.

Key words: Pregnancy, hyperthyroidism, radioactive iodine, fetal hypothyroidism
\end{abstract}

Conflict of interest: None declared Received: 05.12.2011

Accepted: 26.01.2012

\section{Introduction}

Radioiodine (1131) is a convenient, inexpensive, safe and effective treatment for hyperthyroidism and thyroid malignancy in children and adults $(1,2)$. The use of 1131 is absolutely contraindicated during pregnancy principally because of the risk of damaging the fetal thyroid gland and thus leading to hypothyroidism or cretinism $(1,2,3,4,5,6)$. Neonatal hyperthyrotropinemia is observed if the applied dose is below $10 \mathrm{mCi}$ (7). Also, hypothyroidism and hypoparathyroidism can concomitantly occur as a result of maternal radioactive iodine (RAl) treatment (8). Here, we report a young female patient who delivered a hypothyroid baby after she was given RAl treatment accidentally, being unaware that she was at the 12 th week of her pregnancy at the time of therapy.

\section{Case Report}

During the screening programme for congenital hypothyroidism, a fifteen-day old male infant was found twice to have a thyrotropin (TSH) level exceeding $600 \mathrm{mU} / \mathrm{L}$. The patient was referred to the neonatology unit of Erciyes University Faculty of Medicine. Medical history revealed that the mother had received methimazole therapy for 3 weeks due to multiple hyperactive nodules and that this was followed by RAl treatment $(20 \mathrm{mCi})$. Subsequent to this treatment, the mother was detected to be at the $12^{\text {th }}$ week of her pregnancy. It was reported that the 
mother remained euthyroid after the treatment and this was given as the reason why fetal thyroid functions were not measured. The baby was born spontaneously via the vaginal route at the end of a 42-week pregnancy. At birth, body weight was $3840 \mathrm{~g}$, length was $52 \mathrm{~cm}$ and head circumference was $36.5 \mathrm{~cm}$. On the 15th postnatal day, the infant was $55 \mathrm{~cm}$ in length, weight was 4720 $\mathrm{g}$, and head circumference was $37 \mathrm{~cm}$. His anterior fontanelle dimensions were $4 \times 6 \mathrm{~cm}$ and those for the posterior fontanelle were $0.5 \times 0.5 \mathrm{~cm}$. Otherwise, physical examination was normal. The umbilical cord was still undetached.

A plain knee $X$-ray showed findings consistent with a 37-week gestation. Thyroid volume was measured as $0.1 \mathrm{~mL}$ (normal $=0.8$ ) by ultrasonography. Free triiodothyronine was 1.55 $\mathrm{pg} / \mathrm{mL}$ (normal= 2.99-6.66), free thyroxine $2.9 \mathrm{pg} / \mathrm{mL}$ (normal= 6.6-23.7), thyrotropin (TSH) $452 \mathrm{mU} / \mathrm{L}$ (normal= 0.70-18.10), thyroglobulin level $20.1 \mathrm{ng} / \mathrm{mL}$ (normal=91), urine iodine level was $3 \mu \mathrm{g} / \mathrm{dL}$ (normal=10-20 $\mu \mathrm{g} / \mathrm{dL}$ ). TSH receptor antibody level of the maternal serum was $2.4 \mathrm{U} / \mathrm{L}$ (normal=0-10 U/L). The baby was started on L-thyroxine therapy at a dose of $15 \mu \mathrm{g} / \mathrm{kg}$ and is now being followed by our team.

\section{Discussion}

Thyrotoxicosis in pregnancy can be treated using antithyroid drugs as the first choice. Rarely, thyroidectomy can also be an option, but RAl is contraindicated (9). RAl is not used in known pregnancies, but its use in undetected pregnancies is rarely reported $(1,6)$. RAl given to a pregnant woman crosses the placenta rapidly and reaches the fetus (10). After the $12^{\text {th }}$ week of gestation, the fetal thyroid gland starts uptaking and storing iodine (11). Fetal serum RAl level reaches $75 \%$ of mother's serum level and RAl can persist in the fetal thyroid gland for approximately $70-75$ days $(11,12)$. All fetal tissues, and especially the thyroid tissue, are 2-3 times more sensitive to radioactivity as compared to adult tissues (13). RAl concentrated in the thyroid gland causes ablation $(11,13,14)$. As was also the case in our patient, RAl uptake increases and causes more severe injury in iodine-deficient fetuses (15). Therefore, probably due to its total destruction by RAl, the thyroid gland could not be detected by ultrasonography in our patient.

RAl can create a lethal effect on the embryo and can negatively affect brain development both directly by its radioactive effect and indirectly by creating hypothyroidism $(13,14)$. Besides hypothyroidism, a fetus exposed to RAl can have mental retardation, malformations, as well as an increased cancer risk in the later years of its life (16). In some reported cases, hypoechoic thyroid nodules were detected and resolved with thyroxine therapy (17).

To prevent RAl exposure during pregnancy, it is crucial to perform a proper pregnancy test in hyperthyroid female patients and not just rely on medical history. For this purpose, the American College of Radiology has prepared a guideline listing 4 different clinical situations that eliminate the possibility of pregnancy (18). These are: 1- A negative result in a pregnancy test performed within the past 72 hours, 2- A history of hysterectomy, 3- A state of menopause for at least two years, 4A premenarcheal child aged 10 years or younger. Also, one should keep in mind that pregnancy tests relying on urine or serum hCG levels are not totally reliable in the first 8-10 postconceptional days, since implantation may not yet have been completed during this period (19).

In conclusion, for women in reproductive ages who require RAl treatment, the importance of performing a pregnancy test 3 days prior to the treatment needs to be emphasized. If a woman who has received RAl therapy is later detected to be pregnant, fetal thyroid function tests should be undertaken and prenatal treatment should be initiated (6).

\section{References}

1. Evans PM, Webster J, Evans WD, Bevan JS, Scanlon MF. Radioiodine treatment in unsuspected pregnancy. Clin Endocrinol (Oxf) 1998:48:281-283.

2. Lagaru A, McDougall IR. Treatment of thyrotoxicosis. J Nucl Med 2007:48:379-389.

3. Russell KP, Rose $H$, Starr $P$. The effects of radioactive iodine on maternal and fetal thyroid function during pregnancy. Surg Gynecol Obstet 1957;104:560-564.

4. Fisher WD, Voorhess ML, Gardner LI. Congenital hypothyroidism in infant following maternal I131 therapy: With a review of bazards of environmental radioisotope contamination. J Pediatr 1963;62:132-146.

5. Green HG, Gareis FJ, Shepard TH, Kelley VC. Cretinism associated with maternal sodium iodide 1131 therapy during pregnancy. Am J Dis Child 1971;122:247-249.

6. Basbug M, Ozgun MT, Murat N, Batukan C, Ozcelik B, Kurtoglu $\mathrm{S}$. Prenatal diagnosis of fetal hypothyroidism after maternal radioactive iodine exposure during pregnancy. J Clin Ultrasound 2010;38:506-508.

7. Foley T, Malvaux P, Blizzard RM. Thyroid disease. in: Kappy MS, Blizzard RM and Foley T (eds). Wilkins The Diagnosis and Traetment of Endocrine Disorders in Childhood and Adolescent. Springfield: Charles C Thomas Publ 1994;457-520.

8. Richards GE, Brewer ED, Conley SB, Saldana LR. Combined hypothyroidism and hypoparathyroidism in an infant after maternal 131I adminisration. J Pediatr 1981;99:141-143.

9. Stagnaro-Green A. Overt hyperthyroidism and hypothyroidism during pregnancy. Clin Obstet Gynecol 2011;54:478-487.

10. Agency for Toxic Substances and Disease Registry 'Radiation exposure from iodine 131 who is at risk' November 2002, http://unw.atsdr.cdc.gov/csem/iodine/whosat-risk.html.

11. Gorman CA. Radioiodine and pregnancy. Thyroid 1999;9:721726.

12. DiGeorge AM. The endocrine system. In: Behrman RE (ed). Nelson Textbook of Pediatrics, 14th Ed, Philadelphia: WB Saunders Co 1992;1416. 
Kurtoğlu $S$ et al.

Hypothyroidism due to Maternal Radioactive lodine

13. Ogris E. Exposure with J-131 during pregnancy: significance for mother and child. Acta Med Austriaca 1997;24:150-153.

14. Berg GE, Nyström EH, Jacobsson L, Lindberg S, Lindstedt RG, Mattsson S, Niklasson CA, Norén AH, Westphal OG. Radioiodine treatment of hyperthyroidism in a pregnant women. J Nucl Med 1998;39:357-361.

15. Hollowell JG, Hannon WH. Teratogen update: iodine deficiency, a community teratogen. Teratology 1997:55:389-405.

16. Hatch $M$, Brenner A, Bogdanova T, Derevyanko A, Kuptsova $N$, Likhtarev I, Bouville A, Tereshchenko V, Kovgan L, Shpak V, Ostroumova E, Greenebaum E, Zablotska L, Ron E, Tronko M. A screening study of thyroid cancer and other thyroid disease among individuals exposed in utero to iodine-131 from Chernobyl fallout. J Clin Endocrinol Metab 2009;94:899-906.
17. Perry RJ, Ainine A, Butler S, Donaldson MD. Hypoechoic thyroid nodules on ultrasound 4 years after prenatal exposure to radioiodine: resolution with thyroxine therapy. Acta Paediatr 2008;97:509-512.

18. ACR 'Practice Guideline for the Performance of Therapy with Unsealed Radiopharmaceutical Sources' 2005. http://mww.acr.org/Secondary Main Menu Categories/ quality_safety/guidelines/ro/unsealed_radiopharmaceuticals.aspx.

19. Tran P, DeSimone S, Barrett M, Bachrach B. 1131 treatment of graves' disease in an unsuspected first trimester pregnancy; the potential for adverse effects on the fetus and a review of the current guidelines for pregnancy screening. Int J Pediatr Endocrinol 2010;2010:858359. (Epub 2010 Mar 14) 